\title{
Hepatitis B and C infection in haemodialysis patients in Libya: prevalence, incidence and risk factors
}

Wiam A Alashek ${ }^{1 *}$, Christopher W Mclntyre ${ }^{1,2}$ and Maarten W Taal ${ }^{2}$

\begin{abstract}
Background: Patients receiving maintenance haemodialysis (HD) are at higher risk for acquiring Hepatitis B Virus (HBV) and Hepatitis C Virus (HCV) infections than the general population. Strict infection control measures are essential to prevent nosocomial transmission. We aimed to investigate the incidence and prevalence of HBV and HCV infection in the HD population of Libya as well as risk factors for infection.

Methods: All adult patients receiving maintenance HD $(n=2382)$ in Libyan dialysis centres $(n=39)$ were studied between May 2009 and October 2010. Testing for Hepatitis B surface antigen (HBsAg) and anti-HCV antibodies was performed at initiation of dialysis and every 3-6 months thereafter. Patients who were sero-negative for HBV and HCV ( $n=1160)$ were followed up for 1 year to detect sero-conversions.

Results: Participant median age was 49 years and 58\% were male. 831 patients (34.9\%) were sero-positive for HBV and/or HCV (anti-HCV positive 31.1\%; HBsAg positive 2.6\%; both positive 1.2\%). Of the sero-positive patients $4.7 \%$ were known to be infected before the initiation of $\mathrm{HD}$. The prevalence of $\mathrm{HBV} \pm \mathrm{HCV}$ infection varied widely between HD centres from 0\% to 75.9\%. Sero-positive patients were younger, had longer time on dialysis and more previous blood transfusions. Prospective follow-up revealed an incidence of sero-conversion of $7.7 \%$ during 1 year ( $7.1 \% \mathrm{HCV} ; 0.6 \% \mathrm{HBV}$ ). Wide variation in rates of newly acquired infections was observed between dialysis centres. All new HBV cases were referred from centres already treating HBV infected patients. New HCV infections were reported in most centres but the rate of HCV sero-conversion varied widely from $1.5 \%$ to $31 \%$. Duration of dialysis, history of previous renal transplant and history of receiving HD in another centre in Libya were significantly associated with sero-conversion.
\end{abstract}

Conclusion: Patients on maintenance HD in Libya have a high incidence and prevalence of HCV infection and lower rates of HBV infection. The factors associated with HBV and HCV infection are highly suggestive of nosocomial transmission within HD units. Urgent action is required to improve infection control measures in HD centres and to reduce dependence on blood transfusions for the treatment of anaemia.

Keywords: Haemodialysis, Hepatitis B, Hepatitis C, Incidence, Libya, Nosocomial infection, Prevalence

\footnotetext{
* Correspondence: laxwa1@nottingham.ac.uk

${ }^{1}$ School of Graduate Entry Medicine, University of Nottingham, Nottingham, UK

Full list of author information is available at the end of the article
} 


\section{Background}

Chronic infections with Hepatitis B Virus (HBV) and Hepatitis C Virus (HCV) are associated with serious health risks due to hepatic cirrhosis and hepatocellular carcinoma. Patients receiving maintenance haemodialysis (HD) therapy are at increased risk for acquiring these infections and have a higher prevalence of $\mathrm{HBV}$ and $\mathrm{HCV}$ than the general population [1,2]. Prior to effective screening of blood donations, HCV infection was associated with blood transfusions needed to correct the anaemia associated with kidney disease $[3,4]$ but patient to patient transmission in HD units is also reported $[5,6]$. $\mathrm{HBV}$ infection is usually due to patient to patient transmission within HD units [7]. Recognition of the risk of nosocomial infection has resulted in recommendations that strict infection control procedures should be followed on HD units; patients with blood-bourne virus infections should be isolated from sero-negative patients during dialysis and patients as well as staff should be vaccinated against hepatitis $B[8,9]$. The introduction of blood donor screening and a reduction in blood transfusions due to the availability of recombinant erythropoietin has significantly reduced the incidence of new $\mathrm{HCV}$ infections among HD patients in many countries [10-12].

Libya provides free access to maintenance HD for end stage kidney disease through a rapidly expanding network of centres. Although there are no national dialysis practice guidelines or infection control polices enforced by health care authorities, there is general agreement that patients on HD should be screened for HBV and $\mathrm{HCV}$ infection before the initiation of HD and monitored every 3-6 months thereafter [13]. Sero-positive patients are dialysed on dedicated machines either in an isolated area or alongside sero-negative patients if space does not allow isolation [13]. A national serological survey for $\mathrm{HBV}$ and $\mathrm{HCV}$ infections among the general population was performed in Libya during 2003 and revealed prevalences of $2.2 \%$ and $1.2 \%$ for $\mathrm{HBV}$ and $\mathrm{HCV}$, respectively [14]. Other local surveys reported that the rate of HBsAg positivity among blood donors ranged from $1.3 \%$ to $4.6 \%$ [15], while the rate of HCV antibodies was $1.2 \%$ [16]. Global data indicate that the prevalence of $\mathrm{HBV}$ and $\mathrm{HCV}$ infection is high in populations of Africa and the Middle Eastern regions [17-19]. HCV infection was estimated by World Health Organisation to affect $4.6 \%$ of the Eastern Mediterranean population and $5.3 \%$ of the population of Africa [20]. This study aimed to investigate for the first time the incidence and prevalence of HBV and HCV infection in the entire HD population of Libya.

\section{Results}

The median age of adult HD patients included was 49 years (range $36-61$ years) and 58\% were male. A total of 831 patients (34.9\%) were sero-positive for $\mathrm{HBV}$ and/or $\mathrm{HCV}$. The majority of infected patients were positive for anti-HCV antibodies (31.1\%) and 2.6\% were HBsAg positive. Twenty-eight patients (1.2\%) had mixed infection with HBV and HCV (Additional file 1: Table S1). Of the sero-positive patients $4.7 \%$ were known to be infected before the initiation of HD. Overall the prevalence of sero-positivity was similar among males and females (35.8\% versus $33.7 \%$, respectively) but males comprised a greater proportion of those with $\mathrm{HBV}$ or combined infection (Additional file 1: Table S1; $\mathrm{P}=0.01$ for comparison between groups). Hepatitis $\mathrm{B}$ vaccine had been administered in 1216 of 1520 patients but antibody

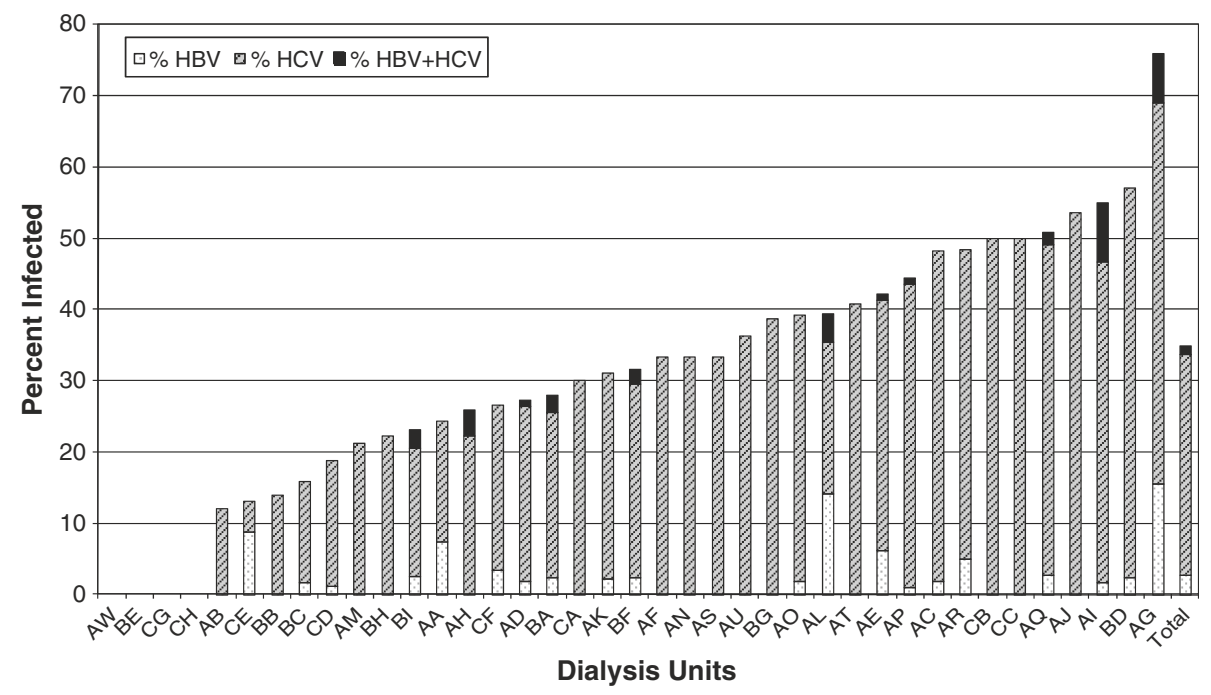

Figure 1 Prevalence of HBV and/or HCV sero-positivity in different haemodialysis centres in Libya. 
levels were not checked post vaccination. Vaccination status was not documented in 862 patients.

The prevalence of $\mathrm{HBV}$ and/or $\mathrm{HCV}$ infection varied widely between HD centres from $0 \%$ to $75.9 \%$. Four centres had no sero-positive patients and half of centres were free from HBV infection. Patients sero-positive for both viruses were found in $28.2 \%$ of centres (Figure 1).

Univariate analysis of potential risk factors for infection with HBV and/or HCV was performed by comparing infected and non-infected patients (Table 1). Seropositive patients were younger and had been receiving dialysis for substantially longer. History and number of blood transfusions was also significantly associated with sero-positivity. Mean values for Alanine Aminotransferase and Aspartate Aminotransferase were higher in seropositive patients despite being within the normal range.

Results of the prospective study showed that 89 of 1160 previously sero-negative patients sero-converted during 1 year (incidence 7.7\%). The majority ( 82 patients) developed anti-HCV antibodies (incidence 7.1\%). Seven patients became positive for $\mathrm{HBsAg}$ (incidence $0.6 \%$ ). Of these one had previously been vaccinated against hepatitis B, four had not been vaccinated and in two vaccination status was not documented. Age and gender distribution of those who sero-converted is shown in Additional file 2: Table S2.

Figure 2 shows wide variation in rates of newly acquired infections between different dialysis centres. No sero-conversion was found in two small-capacity centres (one treating 2 patients and the other, 5 patients). New HBsAg positive cases were detected in 4 centres in $3.3-10.3 \%$ of previously negative patients. All new HBV cases were referred from centres already treating HBV infected patients. New HCV infections were reported in most centres (33 of 35) but the rate of $\mathrm{HCV}$ sero-conversion varied widely from $1.5 \%$ to $31 \%$ of patients. Most of the centres with HCV sero-conversions (31/33) were providing HD treatment to previously $\mathrm{HCV}$-infected patients. However, anti-HCV antibodies were discovered in 9 patients (31\%) in a centre which was previously treating exclusively sero-negative patients (coded CG). Two other HCV sero-conversions occurred in another previously sero-negative HD centre (coded BE).

There were no correlations between number of HD patients treated in each centre and the prevalence or incidence of sero-positivity to HBV or HCV. There was no difference in prevalence or incidence of $\mathrm{HBV}$ or $\mathrm{HCV}$ infection between units that: routinely practiced isolation of sero-positive patients versus those that did not; units with hand washing facilities in each cubicle versus not and units that had adequate facilities for sharps disposal versus not.

Analysis of possible risk factors for new $\mathrm{HBV}$ or $\mathrm{HCV}$ infections is shown in Table 2. Only duration of dialysis, history of previous renal transplant and history of receiving HD in another centre in Libya were significantly different between patients who sero-converted and those who remained sero-negative.

\section{Discussion}

The prevalence of anti-HCV antibodies in patients receiving HD (31.1\%) was remarkably high and is approximately 25 times higher than in the general population [14]. It is also higher than the prevalence of $20.5 \%$

Table 1 Factors potentially associated with HBV and/or HCV infection in haemodialysis centres in Libya

\begin{tabular}{|c|c|c|c|c|c|}
\hline \multirow[t]{2}{*}{ Factors potentially associated with $\mathrm{HBV} \pm \mathrm{HCV}$ infection } & \multicolumn{2}{|c|}{ Sero-positive $\mathrm{N}=831$} & \multicolumn{2}{|c|}{ Sero-negative $\mathrm{N}=1551$} & \multirow[t]{2}{*}{ P- value } \\
\hline & Number* & Value & Number* & Value & \\
\hline Age in years (mean \pm SD) & 831 & $47.1 \pm 14.4$ & 1551 & $49.5 \pm 16.2$ & $<0.001$ \\
\hline Males (number and percent) & 831 & $494(59.4 \%)$ & 1551 & $887(57.2 \%)$ & 0.296 \\
\hline Whites (number and percent) & 805 & $718(89.2 \%)$ & 1528 & $1312(85.9 \%)$ & 0.023 \\
\hline Dialysis vintage in years (median and IQR) & 831 & $6(3-10)$ & 1551 & $2(0.1-3)$ & $<0.001$ \\
\hline Previous blood transfusion (number and percent) & 597 & $482(80.7 \%)$ & 1010 & $688(68.1 \%)$ & $<0.001$ \\
\hline Number of blood transfusions (median and IQR) & 597 & $2(1-3)$ & 1010 & $1(0-3)$ & $<0.001$ \\
\hline Previous renal transplant (number and percent) & 822 & $115(14.0 \%)$ & 1533 & $41(2.7 \%)$ & $<0.001$ \\
\hline Previous dialysis abroad (number and percent) & 617 & $376(60.9 \%)$ & 1025 & $540(52.7 \%)$ & 0.001 \\
\hline Previous dialysis in another Libyan centre (number and percent) & 612 & $324(52.9 \%)$ & 1018 & $447(43.9 \%)$ & $<0.001$ \\
\hline Haemoglobin level in g/dl (mean \pm SD) & 831 & $10.2 \pm 1.9$ & 1551 & $9.7 \pm 1.8$ & $<0.001$ \\
\hline Alanine Aminotransferase in IU/L (mean \pm SD) & 269 & $27.8 \pm 20.2$ & 353 & $19.6 \pm 17.9$ & $<0.001$ \\
\hline Aspartate Aminotransferase in IU/L (mean \pm SD) & 232 & $29.6 \pm 21.1$ & 328 & $21.3 \pm 20.3$ & $<0.001$ \\
\hline Diabetes (number and percent) & 831 & $195(23.5 \%)$ & 1551 & $551(35.5 \%)$ & $<0.001$ \\
\hline Erythropoietin treatment (number and percent) & 604 & $450(74.5 \%)$ & 1059 & $830(78.4 \%)$ & 0.071 \\
\hline
\end{tabular}

*Number of patients with valid data for each variable. 


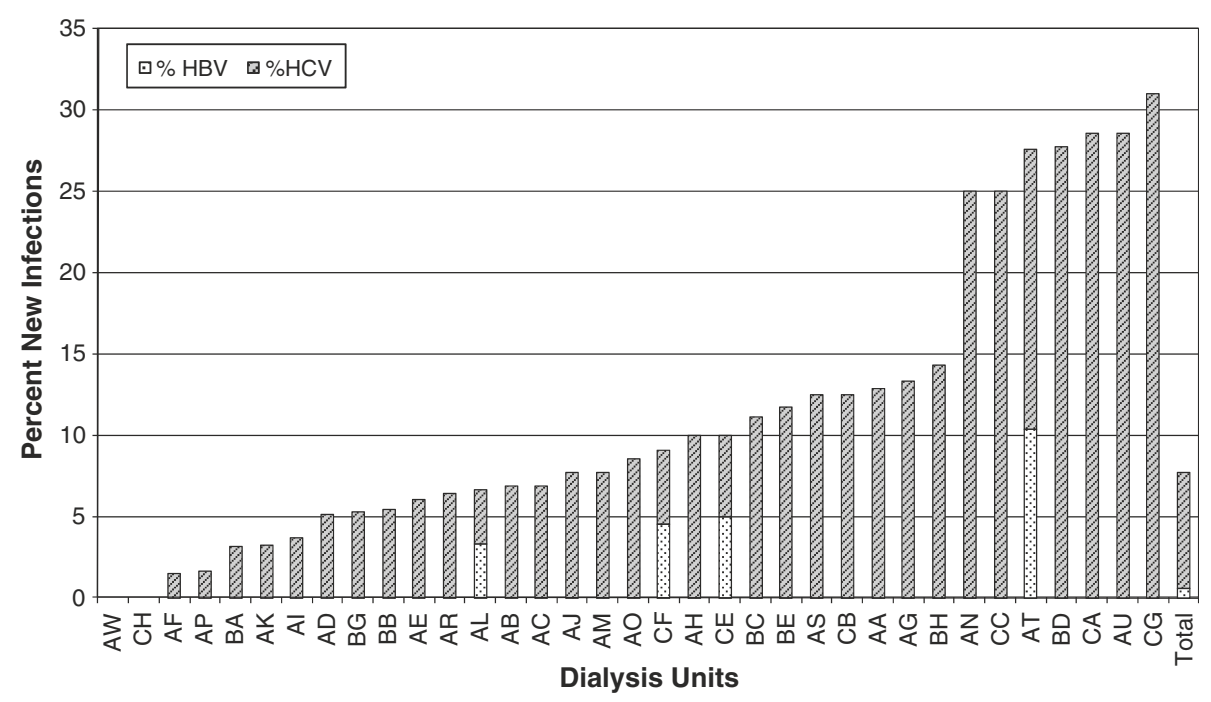

Figure 2 Incidence of new HBV or HCV infections in haemodialysis patients during a 1-year follow up period.

reported by Daw et al. in a sample of $200 \mathrm{HD}$ patients in 2001 in Libya [16]. Globally the prevalence of $\mathrm{HCV}$ among patients receiving HD varies from as low as 6.1\% in Germany [21] to as high as $76 \%$ in Casablanca [22]. In general, North Africa and the Middle East are high prevalence areas both in the general population and in HD patients [20]. Previous studies from the region have reported a prevalence of anti-HCV antibodies in HD patients of $50 \%$ in Saudi Arabia [23], 42\% in Tunisia [24], 20.2\% in Turkey [25] and $21 \%$ in Jordan [26]. In contrast, the observed prevalence of HBV infection $(2.6 \%)$ is similar to the general population and similar to that reported in HD patients in other regions including Europe (4.1\%), Japan (2.2\%) and the USA (2.4\%) [27]. A study sample from the Dialysis Outcome and Practice Patterns Study that included 8615 adult HD patients from 308 dialysis facilities in Western Europe and the United States, reported prevalence rates for HBV infection ranging from $0 \%$ to $6.6 \%$ [28]. Studies from less developed countries estimated that the proportion of HBsAg carriers in the HD population varies from $2 \%$ to 20\% [29-32]. According to the 2008 Saudi Centre for Organ Transplantation (SCOT) report, HBV seropositivity was $4.6 \%$ in the Saudi HD population [33]

Table 2 Factors potentially associated with new HBV or HCV infection in HD centres

\begin{tabular}{|c|c|c|c|c|c|}
\hline \multirow[t]{2}{*}{ Factors potentially associated with new $\mathrm{HBV} \pm \mathrm{HCV}$ infection } & \multicolumn{2}{|c|}{$\begin{array}{l}\text { Sero-converted } \\
\mathrm{N}=89\end{array}$} & \multicolumn{2}{|c|}{$\begin{array}{l}\text { Stayed sero-negative } \\
\qquad \mathrm{N}=1071\end{array}$} & \multirow[t]{2}{*}{ P-value } \\
\hline & Number* & Value & Number* & Value & \\
\hline Age in years (mean \pm SD) & 89 & $50.9 \pm 15.8$ & 1071 & $50 \pm 16.6$ & 0.635 \\
\hline Males (number and percent) & 89 & $54(60.7 \%)$ & 1071 & $613(57.2 \%)$ & 0.528 \\
\hline Whites (number and percent) & 89 & $75(84.3 \%)$ & 1056 & $927(87.8 \%)$ & 0.335 \\
\hline Dialysis vintage in years (mean \pm SD) & 89 & $4.1 \pm 4.4$ & 1071 & $2.2 \pm 2.6$ & 0.001 \\
\hline Previous blood transfusion (number and percent) & 45 & $34(75.6 \%)$ & 716 & $481(67.2 \%)$ & 0.244 \\
\hline Number of blood transfusions (mean \pm SD) & 45 & $3.6 \pm 6.9$ & 716 & $1.8 \pm 2.6$ & 0.083 \\
\hline Previous renal transplant (number and percent) & 89 & $6(6.7 \%)$ & 1064 & $28(2.6 \%)$ & 0.028 \\
\hline Previous dialysis abroad (number and percent) & 48 & $27(56.3 \%)$ & 714 & $395(55.3 \%)$ & 0.900 \\
\hline Previous dialysis in another Libyan centre (number and percent) & 48 & $31(64.6 \%)$ & 707 & $371(52.5 \%)$ & 0.023 \\
\hline Haemoglobin level in g/dl (mean \pm SD) & 89 & $9.9 \pm 2.1$ & 1071 & $9.6 \pm 1.8$ & 0.220 \\
\hline Alanine Aminotransferase in IU/L (mean \pm SD) & 27 & $21.9 \pm 22.7$ & 274 & $18.6 \pm 17.8$ & 0.272 \\
\hline Aspartate Aminotransferase in IU/L (mean \pm SD) & 24 & $23 \pm 23.8$ & 252 & $20.8 \pm 21.2$ & 0.925 \\
\hline Diabetes (number and percent) & 89 & $35(39.3 \%)$ & 1071 & 385 (35.9\%) & 0.524 \\
\hline Erythropoietin treatment (number and percent) & 51 & $7(13.7 \%)$ & 729 & $100(13.7 \%)$ & 0.999 \\
\hline
\end{tabular}


while among Jordanian HD patients it was 5.9\% [34]. In general, the prevalence and incidence of $\mathrm{HBV}$ and $\mathrm{HCV}$ infections in HD patients reflects the prevalence of these infections in the general population, the quality of healthcare services in a community and the standards of infection control practices in HD units. The importance of $\mathrm{HBV}$ and $\mathrm{HCV}$ as a health risk in patients on HD is illustrated by our observation that $3 \%$ of deaths in Libyan HD patients during a 1 year observation period were due to liver failure and that 13 of the 14 patients who died of liver failure were sero-positive for $\mathrm{HCV}$ and/or HBV [35].

Our data show that sero-positive patients were significantly younger on average than sero-negative patients. This observation is in agreement with a previous report from Libya showing that the highest prevalence of $\mathrm{HCV}$ antibodies was observed in HD patients aged 36-55 years [16]. Other studies [28,36,37] have reported a higher prevalence of $\mathrm{HBV}$ or $\mathrm{HCV}$ sero-positivity in older patients and the reason for this difference in not clear. On the other hand, the prevalence and incidence of HBV or HCV sero-positivity was significantly related to the length of time on HD. This is consistent with nosocomial transmission related to dialysis since longer duration of dialysis represents a longer period at risk of acquiring an infection. Similar observations have been reported by other authors [38-41]. Prevention of nosocomial transmission is of vital importance in Libya as $\mathrm{HCV}$ antiviral treatment is expensive and its availability is limited to only a few centres.

A positive history of blood transfusions as well as the number of blood transfusions was strongly associated with $\mathrm{HBV}$ or $\mathrm{HCV}$ infection at baseline, but not with new infections. Prior to the introduction of effective screening of blood donors, blood transfusions were recognised as the leading source of $\mathrm{HCV}$ infection and some of these infections may have been acquired before adequate screening was introduced [21,40]. In addition it is possible that some blood donors with $\mathrm{HCV}$ infection are being missed by current screening procedures and these may need to be reassessed [42,43]. On the other hand the lack of association between blood transfusions and new infections suggests that fewer infections are acquired by this route than previously. A large proportion of patients had previously received blood transfusions. The risk of infection could therefore be further reduced by more effective management of anaemia with iron supplementation and erythropoietin. In accordance with other studies $[41,44,45]$, HBV or HCV infection was more prevalent in patients with a history of previous renal transplant. Infection in these patients might have been transmitted from an infected donor kidney or blood transfused peri-operatively. This observation emphasizes the need for adequate screening of potential kidney donors, which is deficient in some countries. The shortage of donated kidneys in Libya induces many patients to seek a transplant abroad.

Another concern raised by the current study is that $\mathrm{HBV}$ or HCV infection was associated with a history of HD in another centre either in Libya or abroad. Many patients travel for social reasons but some also transfer to a maintenance HD centre after initiating dialysis as an emergency in a specialised centre providing acute services or may travel to another centre for surgery to create an arteriovenous fistula [13]. The association of hepatitis virus infection with travel suggests that the risk of nosocomial infection varies between dialysis centres within Libya and abroad. The former is confirmed by our data showing a marked variation in both prevalence and incidence of HBV and HCV infection among Libyan HD units (Figures 1 and 2). These observations emphasize the importance of isolating patients following their return and monitoring them for sero-conversion.

Prospective follow up of sero-negative HD patients enabled us to verify 89 sero-conversions for HBV or $\mathrm{HCV}$ during 1 year, giving an overall incidence of $7.7 \%$ for new infections. The incidence rate of $0.6 \%$ for $\mathrm{HBsAg}$ sero-conversion is similar to that reported in Europe, Japan and the USA (0.4-1.8 per 100 patient-years) [28]. Three new HBsAg positive patients were detected in a single centre that was treating 20 other HBsAg positive patients and 2 new cases were detected in another centre that was treating $14 \mathrm{HBsAg}$ positive patients, suggesting that nosocomial transmission probably occurred. We observed a high incidence of new HCV infections during the 1-year observation period (7.2\%). The reported incidence of new $\mathrm{HCV}$ infections varies considerably between countries. A rate as low as $0.4 \%$ was observed in France from 1997 to 2000 [46] but higher rates have been reported from the Mediterranean region. According to the 2008 SCOT report, the annual rate of HCV sero-conversion in Saudi HD patients was 7-9\% [33] while in Jordan it was $2.6 \%$ [26]. In our study most new cases were observed in centres treating other patients with $\mathrm{HCV}$ infection, suggesting nosocomial transmission. Interestingly 9 new $\mathrm{HCV}$ infections were observed in one unit and 2 in another that previously accepted only patients without $\mathrm{HCV}$ infection. This raises the possibility of transmission from a carrier that was not detected by current screening procedures.

A striking observation from this study is the wide variation in incidence and prevalence of $\mathrm{HBV}$ and $\mathrm{HCV}$ infections among different HD units (Figures 1 and 2). Interestingly none of the potential centre-related factors that we assessed formally explained this variation. On the other hand, we observed variations in other practices that may be relevant. Most facilities faced a problem of increasing number of patients and most of them 
responded by adding more HD stations at expense of space and staff. Infection control precautions also varied widely between centres. They were strictly enforced in some places but frequently breached in others. This seemed to depend on staff initiative rather than national guidelines. On the other hand, dialyser reuse was not permitted and all bloodlines as well as other consumables were disposed after a single use [13]. Some brands of HD machines were equipped with a sphygmomanometer. Otherwise, most non- disposable instruments used in HD environment were shared between sero-positive and sero-negative patients. The use of multi-dose vials of heparin was common and is likely to have been an important cause of nosocomial infections. Many patients started HD without being vaccinated against HBV. Even in vaccinated patients the antibody titre was not assessed. The wide variation in HBV and HCV prevalence and incidence between dialysis centres implies that there is potential to reduce blood-borne virus infection by transferring best practice from HD centres with low infection rates. In particular infection control procedures should be investigated in centres with high infection rates and the use of multidose heparin vials must be stopped urgently. Previous studies from the region show that with appropriate intervention $\mathrm{HCV}$ infection rates in HD centres may be substantially improved. For example in Iran, HCV prevalence reduced from $14.4 \%$ in 1999 to $4.5 \%$ in 2006 [47] and in Saudi Arabia from $2.4 \%$ in 2001 to $0.2 \%$ in 2005 [48].

Several limitations of this study should be conceded. Medical records were often incomplete and additional clinical information was frequently obtained by interviewing staff and patients. Serological testing was done in local laboratories and it is likely that there was some variation in the quality of testing. Data regarding hepatitis B core antibodies ( $\mathrm{HBcAb})$ or hepatitis B DNA were not available. In one recent study of haemodialysis patients in Egypt who were negative for $\mathrm{HBsAg}$, hepatitis B DNA was detected in $4.1 \%$ and HBcAb in $20 \%$ [49]. It is therefore possible that we failed to detect cases of occult hepatitis B infection. Testing for $\mathrm{HCV}$ relied on a third generation ELISA to detect anti-HCV antibodies and confirmation or genotyping with PCR is currently not available in most centres.

\section{Conclusion}

In conclusion, patients on maintenance HD in Libya have a high incidence and prevalence of $\mathrm{HCV}$ infection and lower rates of $\mathrm{HBV}$ infection. The factors associated with $\mathrm{HBV}$ and $\mathrm{HCV}$ infection are highly suggestive of nosocomial transmission within HD units. Urgent action is required to improve infection control measures in HD centres and to reduce dependence on blood transfusions for the treatment of anaemia. The data presented were obtained before the recent conflict in Libya. It is possible that disruption of services due to the conflict may have exacerbated the problem of hepatitis virus infection in HD patients.

\section{Methods}

This descriptive study was carried out in all HD centres treating adult patients in Libya $(n=39)$ from May 2009 to October 2010. Phase I of the study was a collection of cross-sectional data regarding all adult patients in maintenance HD facilities $(n=2382)$. Large and medium capacity HD facilities were visited by the researchers in order to collect data. Patient records were used to obtain patients' age, gender, time on HD, medical history, seropositivity to $\mathrm{HBV}$ and $\mathrm{HCV}$ as well as other laboratory results. Sero-positivity to HBV was defined by detection of hepatitis B surface antigen (HBsAg) and seropositivity to $\mathrm{HCV}$ by detection of anti-HCV antibodies by a third generation enzyme linked immunoassay (ELISA). ELISA tests were performed in local laboratories. In addition, 1732 patients from 24 centres were interviewed regarding other potential risk factors for $\mathrm{HBV}$ and $\mathrm{HCV}$ infection. These included history of blood transfusions and history of HD in another centre within Libya or abroad. Data was also obtained regarding infection control procedures at each HD facility. For small and remote facilities, data collection forms were posted to clinical supervisors who were requested to collect information about their patients. They were contacted frequently by phone to deal with any queries related to the required variables. Forms were returned within 30 days.

Phase II of the study was to prospectively detect seroconversion to $\mathrm{HBV}$ or $\mathrm{HCV}$ in previously sero-negative HD patients during 1 year of follow-up. This step included a cohort of 1160 patients from 35 centres (four centres were excluded because of incomplete information). All sero-conversions were recorded and included even if patient was transplanted or died afterwards. The research team frequently monitored HD patients during the year to assure the inclusion of every new seroconversion. All new sero-conversions were retested to confirm the positive result. Field visits were repeated at the end of 1 year to validate the information.

Data are presented as mean \pm SD if normally distributed or median (interquartile range) if not. Analysis was performed using SPSS version 16.0. A Chi-square test was used to compare frequencies between groups. Correlations were tested with a Pearson's test. A t-test was used to compare means between groups for data with normal distribution or Mann-Whitney test for non-parametric data

Permission to conduct the study was granted from the ministry of health. The project was approved by the 
Libyan National Committee for Bioethics and Bio-safety. Patients gave written informed consent to be interviewed. The study was performed by a Libyan researcher with support from a Nephrology Department in the UK.

\section{Additional files}

Additional file 1: Table S1. Frequency, age and gender distribution of HBV and/or HCV sero-positive haemodialysis patients. Data are number (percent) or median (interquartile range).

Additional file 2: Table S2. Frequency, age and gender distribution of patients who sero-converted during 1 year of follow-up. Data are number (percent) or median (interquartile range)

\section{Competing interests}

The authors have no conflicts of interest to declare. The results presented in this paper have not been published previously in whole or part, except in abstract form.

\section{Authors' contributions}

The contribution of each of the authors was as follows: WA: study design, collection of all data, analysis of data, writing of manuscript. CWM: study design, review of data, writing and revision of manuscript. MWT: study design, review of data, writing and revision of manuscript. All authors read and approved the final manuscript

\section{Authors' information}

WA is based in Libya and conducted this study as part of a PhD project, supervised by CWM and MWT, who are consultant nephrologists in the UK.

\section{Acknowledgments}

We would like to express our gratitude to the Libyan National Authority for Scientific Research (NASR) and the teaching and research staff in the Department of Community Medicine in Tripoli University for invaluable assistance in gathering data as well as healthcare teams in Libyan dialysis facilities for their cooperation.

\section{Author details}

${ }^{1}$ School of Graduate Entry Medicine, University of Nottingham, Nottingham, UK. ${ }^{2}$ Department of Renal Medicine, Derby Hospitals NHS Foundation Trust, Derby, UK.

Received: 25 January 2012 Accepted: 16 October 2012

Published: 20 October 2012

\section{References}

1. Fabrizi F, Poordad FF, Martin P: Hepatitis C infection and the patient with end-stage renal disease. Hepatology 2002, 36(1):3-10.

2. Fabrizi F, Lunghi $G$, Martin P: Hepatitis $B$ virus infection in hemodialysis: recent discoveries. J Nephrol 2002, 15(5):463-468.

3. Taal MW, van Zyl-Smit R: Hepatitis $C$ virus infection in chronic haemodialysis patients-relationship to blood transfusions and dialyser re-use. S Afr Med J 2000, 90(6):621-625.

4. Knudsen F, Wantzin P, Rasmussen K, Ladefoged SD, Lokkegaard N, Rasmussen LS, Lassen A, Krogsgaard K: Hepatitis C in dialysis patients: relationship to blood transfusions, dialysis and liver disease. Kidney Int 1993, 43(6):1353-1356.

5. Allander T, Medin C, Jacobson SH, Grillner L, Persson MA: Hepatitis C transmission in a hemodialysis unit: molecular evidence for spread of virus among patients not sharing equipment. J Med Virol 1994, 43(4):415-419.

6. Le Pogam S, Le Chapois D, Christen R, Dubois F, Barin F, Goudeau A: Hepatitis $C$ in a hemodialysis unit: molecular evidence for nosocomial transmission. J Clin Microbiol 1998, 36(10):3040-3043.

7. Ozer A, Yakupogullari Y, Beytur A, Beytur L, Koroglu M, Salman F, Aydogan F: Risk factors of hepatitis B virus infection in turkey: a population-based, case-control study: risk factors for HBV infection. Hepat Mon 2011, 11(4):263-268
8. Fabrizi F, Marzano A, Messa P, Martin P, Lampertico P: Hepatitis B virus infection in the dialysis population: current perspectives. Int J Artif Organs 2008, 31(5):386-394.

9. Taal MW, van Zyl-Smit R: Cost-effectiveness of hepatitis B vaccination in haemodialysis patients. S Afr Med J 2001, 91(4):340-344.

10. Mohamed WZ: Prevention of hepatitis $C$ virus in hemodialysis patients: five years experience from a single center. Saudi J Kidney Dis Transp/ 2010, 21(3):548-554

11. Patel PR, Thompson ND, Kallen AJ, Arduino MJ: Epidemiology, surveillance, and prevention of hepatitis $C$ virus infections in hemodialysis patients. Am J Kidney Dis 2010, 56(2):371-378.

12. Saune K, Kamar N, Miedouge M, Weclawiak H, Dubois M, Izopet J, Rostaing $\mathrm{L}$ : Decreased prevalence and incidence of HCV markers in haemodialysis units: a multicentric French survey. Nephrol Dial Transplant 2010, 26(7):2309-2316

13. Alashek WA, Mclntyre CW, Taal MW: Provision and quality of dialysis services in Libya. Hemodial Int 2011, 15(4):444-452.

14. Elzouki A, Esmeo M, Samod M, Abonaja A, Alagi B, Daw M: Prevalence of hepatitis B, C and HIV infection in Libya: a population-based nationwide seropepidemiological study. Liver Int 2006, 26:20.

15. Elzouki AN: Hepatitis B infection in Libya:The magnitude of the problem. The Libyan Journal of Infectious Diseases 2008, 2(1):20-25.

16. Daw MA, Elkaber MA, Drah AM, Werfalli MM, Mihat AA, Siala IM: Prevalence of hepatitis $C$ virus antibodies among different populations of relative and attributable risk. Saudi Med J 2002, 23(11):1356-1360.

17. Frank C, Mohamed MK, Strickland GT, Lavanchy D, Arthur RR, Magder LS, El Khoby T, Abdel-Wahab Y, Aly Ohn ES, Anwar W, et al: The role of parenteral antischistosomal therapy in the spread of hepatitis $C$ virus in Egypt. Lancet 2000, 355(9207):887-891.

18. Lavanchy D: The global burden of hepatitis C. Liver Int 2009, 29(Suppl 1):74-81.

19. Te HS, Jensen DM: Epidemiology of hepatitis B and C viruses: a global overview. Clin Liver Dis 2010, 14(1):1-21. vii.

20. WHO: Global surveillance and control of hepatitis C. Report of a WHO consultation organized in collaboration with the viral hepatitis prevention board, antwerp, belgium. J Viral Hepat 1999, 6(1):35-47.

21. Hinrichsen $H$, Leimenstoll G, Stegen G, Schrader H, Folsch UR, Schmidt WE: Prevalence and risk factors of hepatitis $C$ virus infection in haemodialysis patients: a multicentre study in 2796 patients. Gut 2002, 51(3):429-433.

22. Boulaajaj K, Elomari Y, Elmaliki B, Madkouri B, Zaid D, Benchemsi N: Prevalence of hepatitis $C$, hepatitis $B$ and HIV infection among haemodialysis patients in Ibn-rochd university hospital, casablanca. Nephrol Ther 2005, 1(5):274-284.

23. Souqiyyeh MZ, Al-Attar MB, Zakaria H, Shaheen FA: Dialysis centers in the kingdom of saudi arabia. Saudi J Kidney Dis Transp/ 2001, 12(3):293-304.

24. Jemni S, Ikbel K, Kortas M, Mahjoub J, Ghachem L, Bidet JM, Boukef K: Seropositivity to hepatitis $C$ virus in Tunisian haemodialysis patients. Nouv Rev Fr Hematol 1994, 36(5):349-351.

25. Yakaryilmaz F, Gurbuz OA, Guliter S, Mert A, Songur Y, Karakan T, Keles H: Prevalence of occult hepatitis $B$ and hepatitis $C$ virus infections in Turkish hemodialysis patients. Ren Fail 2006, 28(8):729-735.

26. Batieha A, Abdallah S, Maghaireh M, Awad Z, Al-Akash N, Batieneh A, Ajlouni KA: Epidemiology and cost of haemodialysis in Jordan. East Mediterr Health J 2007, 13(3):654-663.

27. Goodkin DA, Young EW, Kurokawa K, Prutz KG, Levin NW: Mortality among hemodialysis patients in europe, japan, and the united states: case-mix effects. Am J Kidney Dis 2004, 44(5 Suppl 2):16-21.

28. Burdick RA, Bragg-Gresham JL, Woods JD, Hedderwick SA, Kurokawa K Combe C, Saito A, LaBrecque J, Port FK, Young EW: Patterns of hepatitis B prevalence and seroconversion in hemodialysis units from three continents: the DOPPS. Kidney Int 2003, 63(6):2222-2229.

29. Ferreira RC, Teles SA, Dias MA, Tavares VR, Silva SA, Gomes SA, Yoshida CF, Martins RM: Hepatitis B virus infection profile in hemodialysis patients in Central Brazil: prevalence, risk factors, and genotypes. Mem Inst Oswaldo Cruz 2006, 101(6):689-692.

30. Chandra M, Khaja MN, Hussain MM, Poduri CD, Farees N, Habeeb MA Krishnan S, Ramareddy GV, Habibullah CM: Prevalence of hepatitis B and hepatitis $C$ viral infections in Indian patients with chronic renal failure. Intervirology 2004, 47(6):374-376.

31. Qadi AA, Tamim H, Ameen G, Bu-Ali A, Al-Arrayed S, Fawaz NA, Almawi WY: Hepatitis $B$ and hepatitis $C$ virus prevalence among dialysis patients in 
Bahrain and Saudi Arabia: a survey by serologic and molecular methods. Am J Infect Control 2004, 32(8):493-495.

32. Telaku S, Fejza H, Elezi Y, Bicaj T: Hepatitis B and C in dialysis units in Kosova. Virol J 2009, 6:72

33. SCOT: Saudi centre for organ transplantation- annual report 2009. 2009. (https://www.scot.org.sa/en/) accessed July 2010

34. Al Hijazat M, Ajlouni YM: Hepatitis B infection among patients receiving chronic hemodialysis at the royal medical services in jordan. Saudi J Kidney Dis Transp/ 2008, 19(2):260-267.

35. Alashek WA, Mclntyre CW, Taal MW: Determinants of survival in patients receiving dialysis in Libya. Hemodial Int 2012, doi:10.1111/j.1542-4758.2012.00728.x [Epub ahead of print].

36. Saxena AK, Panhotra BR: The vulnerability of middle-aged and elderly patients to hepatitis $C$ virus infection in a high-prevalence hospitalbased hemodialysis setting. J Am Geriatr Soc 2004, 52(2):242-246.

37. Mostaghni AA, Soltanian A, Mokhtari E, Japoni S, Mehrabani D: Seroprevalence of hepatitis $B$ virus among hemodialysis patients in Bushehr province, southern Iran: HBV seroprevalence in hemodialysis patients. Hepat Mon 2011, 11(3):200-202.

38. Hardy NM, Sandroni S, Danielson S, Wilson WJ: Antibody to hepatitis C virus increases with time on hemodialysis. Clin Nephrol 1992, 38(1):44-48.

39. Jasuja S, Gupta AK, Choudhry R, Kher V, Aggarwal DK, Mishra A, Agarwal M, Sarin A, Mishra MK, Raina V: Prevalence and associations of hepatitis C viremia in hemodialysis patients at a tertiary care hospital. Indian J Nephrol 2009, 19(2):62-67.

40. Vladutiu DS, Cosa A, Neamtu A, State D, Braila M, Gherman M, Patiu IM, Dulau-Florea I: Infections with hepatitis $B$ and $C$ viruses in patients on maintenance dialysis in Romania and in former communist countries: yellow spots on a blank map? J Viral Hepat 2000, 7(4):313-319.

41. Fissell RB, Bragg-Gresham JL, Woods JD, Jadoul M, Gillespie B, Hedderwick SA, Rayner HC, Greenwood RN, Akiba T, Young EW: Patterns of hepatitis $C$ prevalence and seroconversion in hemodialysis units from three continents: the DOPPS. Kidney Int 2004, 65(6):2335-2342.

42. Hitzler WE, Runkel S: Routine HCV PCR screening of blood donations to identify early HCV infection in blood donors lacking antibodies to HCV. Transfusion 2001, 41(3):333-337.

43. Doghman NA MYA, Najem FI, SA E-S: Blood donor screening for hepatitis B and C in Benghazi: additional tests are needed. Libyan J Infect Dis 2007, 1(1):100-102.

44. Pereira BJ: Hepatitis $\mathrm{C}$ infection and post-transplantation liver disease. Nephrol Dial Transplant 1995, 10(Suppl 1):58-67.

45. Dusheiko G, Song E, Bowyer S, Whitcutt M, Maier G, Meyers A, Kew MC: Natural history of hepatitis $B$ virus infection in renal transplant recipients-a fifteen-year follow-up. Hepatology 1983, 3(3):330-336.

46. Izopet J, Sandres-Saune K, Kamar N, Salama G, Dubois M, Pasquier C, Rostaing L: Incidence of HCV infection in French hemodialysis units: a prospective study. J Med Virol 2005, 77(1):70-76.

47. Alavian SM, Bagheri-Lankarani K, Mahdavi-Mazdeh M, Nourozi S: Hepatitis B and $C$ in dialysis units in Iran: changing the epidemiology. Hemodial Int 2008, 12(3):378-382.

48. Karkar A, Abdelrahman M, Ghacha R, Malik TQ: Prevention of viral transmission in HD units: the value of isolation. Saudi I Kidney Dis Transpl 2006, 17(2):183-188.

49. Abu El Makarem MA, Abdel Hamid M, Abdel Aleem A, Ali A, Shatat M, Sayed D, Deaf A, Hamdy L, Tony EA: Prevalence of occult hepatitis B virus infection in hemodialysis patients from egypt with or without hepatitis C virus infection. Hepat Mon 2012, 12(4):253-258.

\section{Submit your next manuscript to BioMed Central and take full advantage of:}

- Convenient online submission

- Thorough peer review

- No space constraints or color figure charges

- Immediate publication on acceptance

- Inclusion in PubMed, CAS, Scopus and Google Scholar

- Research which is freely available for redistribution

Submit your manuscript at www.biomedcentral.com/submit
C Biomed Central 